Check for updates

Cite this: RSC Adv., 2018, 8, 32016

\title{
Partial denitrification coupled with immobilization of anammox in a continuous upflow reactor
}

\author{
Weiqi Wang, Xiujie Wang, (D) * Siyu Wang and Jun Li (D) *
}

Based on the stable operation of a continuous upflow reactor, immobilized anammox coupling with partial denitrification (DEAMOX), was successfully achieved after 94 days operation with a $63.5 \%$ accumulation rate of $\mathrm{NO}_{2}{ }^{-}-\mathrm{N}$ and a $98.4 \%$ removal rate of $\mathrm{NO}_{3}{ }^{-}-\mathrm{N}$. Moreover, the findings show that the optimum range of $\mathrm{COD} / \mathrm{NO}_{3}{ }^{-}-\mathrm{N}$ ratio for the coupling reaction was 2.3-2.7. The nitrogen removal performance of the coupling reactor decreased in response to the increase of $\mathrm{pH}$ value to 8.0 or 8.5 , which was inconsistent with previously published results. Complete denitrification was successfully coupled with DEAMOX by adding polycaprolactone (PCL) as solid carbon source. As a result, the $\mathrm{NO}_{3}{ }^{-}-\mathrm{N}$ produced via anaerobic ammonium oxidation could be completely removed; the removal rate of total nitrogen increased from $80.3 \%$ to $88.5 \%$. In addition, a large number of denitrifying biofilms were attached to the surface of PCL particles.

Received 2nd July 2018

Accepted 5th September 2018

DOI: $10.1039 / \mathrm{c} 8 \mathrm{ra0} 5649 \mathrm{~h}$

rsc.li/rsc-advances

stably operated for 180 days. Li et al. ${ }^{9}$ seeded the bottom of a single continuous upflow reactor with partial-denitrification sludge from a continuous upflow reactor and loaded anammox sludge in the upper part, thus successfully achieving the coupling of partial denitrification and anammox. The reason why the above achieved this process was that they both had successfully acclimated denitrification sludge with high nitrite nitrogen accumulation, which was directly added into the reactor. However, they neglected the exploration about how to directly start up the DEAMOX process. Moreover, they obtained partial-denitrification sludge with specific methods, which was complicated.

In this study, based on the continuous upflow reactor of immobilized anammox that had been successfully started and stably operated, glucose was used as the sole carbon source to explore both the start-up and operation of the DEAMOX process in a continuous upflow reactor. ${ }^{10}$ The anammox coupling with partial denitrification was achieved by gradually increasing the concentration of $\mathrm{NO}_{3}{ }^{-}-\mathrm{N}$ in the influent while constantly adjusting the $\mathrm{COD} / \mathrm{NO}_{3}{ }^{-}-\mathrm{N}$ ratio. During the start-up process, the anammox could obtain more electron acceptors $\left(\mathrm{NO}_{2}{ }^{-}-\mathrm{N}\right)$ due to the continuous improvement of the partial denitrification efficiency. Exogenous $\mathrm{NO}_{2}{ }^{-}-\mathrm{N}$ was gradually decreased until the electron acceptors $\mathrm{NO}_{2}{ }^{-}-\mathrm{N}$ of anammox could be completely provided by the partial denitrification process. The effect of the $\mathrm{pH}$ on the nitrogen removal efficiency of the coupling system was also investigated. Finally, a solid carbon source was added in the coupling terminal of the coupling process to further couple the whole denitrification and to remove the nitrate nitrogen produced via anaerobic ammonia oxidation, which promoted the removal rate of total nitrogen. The long-term performance of the combination of the partial denitrification, anammox, and the complete denitrification in
The College of Architecture and Civil Engineering, Beijing University of Technology, Beijing 100124, China.E-mail: 18810925108@163.com; lijun_bga@163.com; Fax: +86 (010) 67391726; Tel: +86 (010) 67391726 


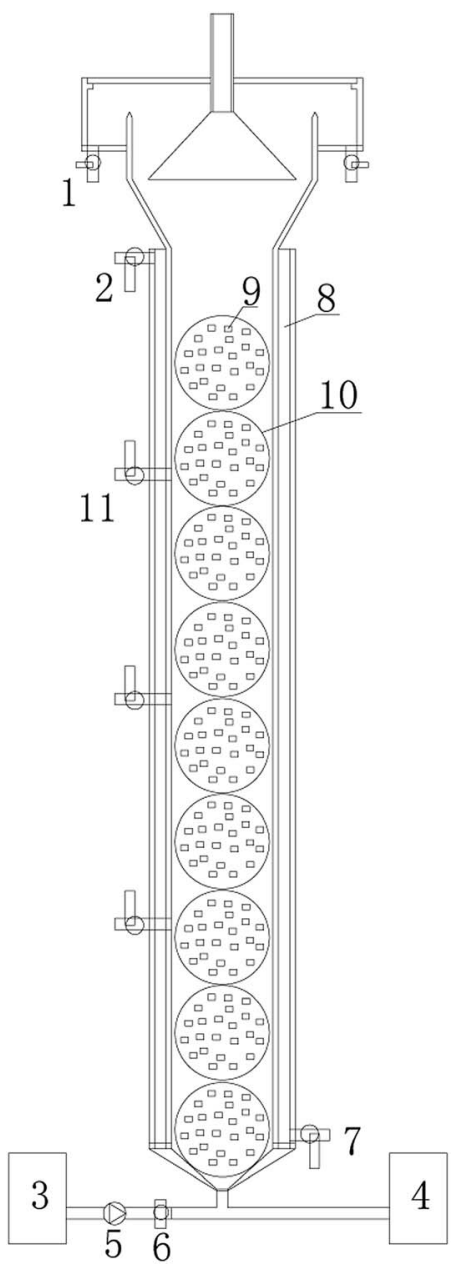

Fig. 1 Partial denitrification coupled with immobilization of anammox reactor 1-outlet; 2-water jacket outlet; 3-influent $\left(\mathrm{NH}_{4}{ }^{+}-\mathrm{N}, \mathrm{NO}_{2}{ }^{-}-\mathrm{N}\right.$, $\mathrm{NO}_{3}{ }^{-}-\mathrm{N}$ ); 4-influent (COD); 5-peristaltic pump; 6-valve; 7-water jacket inlet; 8-water jacket; 9-immobilized pellets; 10 -flow separated ball; 11-sampling outlet at different heights of reactor.

a single reactor was investigated. In summary, a novel DEAMOX-complete denitrification process was established in this study for the simultaneous treatment of $\mathrm{NO}_{3}{ }^{-}-\mathrm{N}$ containing wastewater and $\mathrm{NH}_{4}{ }^{+}-\mathrm{N}$ containing sewage, as a cost-saving and efficient method.

\section{Materials and methods}

\subsection{Synthetic wastewater}

For continuous feeding tests, a synthetic medium was used. The synthetic medium contained (per liter): $0.5 \mathrm{~g} \mathrm{KHCO}_{3} ; 0.0272 \mathrm{~g}$ $\mathrm{KH}_{2} \mathrm{PO}_{4} ; 0.3 \mathrm{~g} \mathrm{MgSO}_{4} ; 0.18 \mathrm{~g} \mathrm{CaCl}_{2}$; and $1 \mathrm{ml}$ trace element solutions A and B. Trace element solution A contained (per liter): $5 \mathrm{~g}$ EDTA and $5 \mathrm{~g} \mathrm{FeSO}_{4}$; trace element solution B contained (per liter): $15 \mathrm{~g}$ EDTA; $0.43 \mathrm{~g} \mathrm{ZnSO}_{4} \cdot 7 \mathrm{H}_{2} \mathrm{O} ; 0.24 \mathrm{~g}$ $\mathrm{CoCl}_{2} \cdot 6 \mathrm{H}_{2} \mathrm{O} ; 0.99 \mathrm{~g} \mathrm{MnCl}_{2} \cdot 4 \mathrm{H}_{2} \mathrm{O} ; 0.25 \mathrm{~g} \mathrm{CuSO} \cdot 5 \mathrm{H}_{2} \mathrm{O} ; 0.22 \mathrm{~g}$ $\mathrm{NaMoO}_{4} \cdot 2 \mathrm{H}_{2} \mathrm{O} ; 0.19 \mathrm{~g} \mathrm{NiCl} \cdot 6 \mathrm{H}_{2} \mathrm{O} ; 0.21 \mathrm{~g} \mathrm{NaSeO} \cdot 10 \mathrm{H}_{2} \mathrm{O}$; and $0.014 \mathrm{~g} \mathrm{H}_{3} \mathrm{BO}_{4} \cdot \mathrm{NH}_{4}{ }^{+}-\mathrm{N}, \mathrm{NO}_{2}{ }^{-}-\mathrm{N}$, and $\mathrm{NO}_{3}{ }^{-}-\mathrm{N}$ were prepared via $\mathrm{NH}_{4} \mathrm{Cl}, \mathrm{NaNO}_{2}$, and $\mathrm{NaNO}_{3}$, respectively.

\subsection{Experimental procedure}

2.2.1 Continuous apparatus. The experimental apparatus consisted of a continuous upflow reactor with a height of $1 \mathrm{~m}$, an inner diameter of $90 \mathrm{~mm}$, and an effective volume of $6 \mathrm{~L}$ (Fig. 1). The outer part was equipped with a water bath layer. The immobilized anaerobic ammonium oxidation particles were supported by a braided filler within flow-separated balls, and were evenly distributed in the reactor.

2.2.2 Start-up of the DEAMOX process. This study was based on a continuous upflow reactor of anaerobic ammoniumoxidizing bacteria, immobilized in a polyethylene glycol gel carrier, which had been successfully started up and operated stably. ${ }^{11}$ Both influent containing ammonium and nitrite at 30 and $45 \mathrm{mg}-\mathrm{N} \mathrm{L}^{-1}$ were supplied to the reactor, respectively. The ratios of $\mathrm{NO}_{2}{ }^{-}-\mathrm{N} / \mathrm{NH}_{4}{ }^{+}-\mathrm{N}$ and $\mathrm{NO}_{3}{ }^{-}-\mathrm{N} / \mathrm{NH}_{4}{ }^{+}-\mathrm{N}$ in anammox process were about 1.25 and 0.25 , which was close to the theoretical values of 1.32 and 0.26 . On the $6^{\text {th }}$ day, $10 \mathrm{mg} \mathrm{L}^{-1}$ $\mathrm{NO}_{3}{ }^{-}-\mathrm{N}$ was added to the influent and its impact on anaerobic ammonium oxidation was investigated. On the $11^{\text {th }}$ day, the dosage of $\mathrm{NO}_{3}{ }^{-}-\mathrm{N}$ was increased to about $40 \mathrm{mg} \mathrm{L}^{-1}$ to match the need for partial denitrification coupling anammox. During phase IV, $10 \mathrm{mg} \mathrm{L}^{-1} \mathrm{COD}$ was added to the influent to culture partial denitrifying bacteria. During phase $\mathrm{V}$, the COD of influent increased to $60 \mathrm{mg} \mathrm{L^{-1 }}$ to enhance the capacity of partial denitrification. During phase VI, the influent COD increased to $120 \mathrm{mg} \mathrm{L}^{-1}$. Furthermore, the concentration of $\mathrm{NO}_{2}{ }^{-}-\mathrm{N}$ in the influent decreased to $15 \mathrm{mg} \mathrm{L}^{-1}$ on the $50^{\text {th }}$ day. During phase VIII, the concentration of $\mathrm{NO}_{2}{ }^{-}-\mathrm{N}$ in the influent was 0 . During phase IX, the ratio of $\mathrm{COD} / \mathrm{NO}_{3}{ }^{-}-\mathrm{N}$ was adjusted to explore the best conditions for coupling (Table 1).

2.2.3 Increasing the $\mathrm{pH}$ to investigate the coupling performance. A previous study of anammox showed that the optimum $\mathrm{pH}$ range for anaerobic ammonium oxidation was 7.5-8.5. ${ }^{12}$ In this experiment, the $\mathrm{pH}$ of the influent was controlled to be $7.5 \pm 0.1$. Next, the $\mathrm{pH}$ was increased to 8.0 and 8.5 after a long-term operation for 94 days. In addition, the $\mathrm{pH}$ was increased to a reasonable range according to anammox. Its impact on the nitrite nitrogen accumulation of the partial denitrification coupling with immobilized anammox was explored.

2.2.4 Effect of PCL on the performance of DEAMOX process. A small amount of nitrate nitrogen was produced during the production stage of anaerobic ammonium oxidation, which influenced the contribution of anaerobic ammonium oxidation to the total nitrogen removal rate. Therefore, in this study, based on partial denitrification coupling and embedding anaerobic ammonium oxidation, about $100 \mathrm{~g}$ of the solid carbon source polycaprolactone (PCL) was added at the top of the continuous upflow reactor to remove the nitrate nitrogen produced by anammox.

\subsection{Calculation method of nitrite nitrogen accumulation rate (NTR)}

Eqn (1) is the anaerobic ammonium oxidation reaction equation. In theory, the consumption/production ratio of $\mathrm{NH}_{4}{ }^{+}-\mathrm{N}$, $\mathrm{NO}_{2}{ }^{-} \mathrm{N}$, and $\mathrm{NO}_{3}{ }^{-}-\mathrm{N}$ is $1: 1.32: 0.26$; the actual operation 
Table 1 Operation mode of reactor

\begin{tabular}{llllll}
\hline & & \multicolumn{2}{l}{ Influent nitrogen concentration $\left(\mathrm{mg} \mathrm{L}^{-1}\right)$} & \\
\cline { 3 - 5 } Phase & Day & $\mathrm{NH}_{4}{ }^{+}-\mathrm{N}$ & $\mathrm{NO}_{3}{ }^{-}-\mathrm{N}$ & $\mathrm{NO}_{2}{ }^{-}-\mathrm{N}$ & COD concentration $\left(\mathrm{mg} \mathrm{L}^{-1}\right)$ \\
\hline I & $0-5$ & 30 & - & 45 & - \\
II & $6-10$ & 30 & 13 & 45 & - \\
III & $11-15$ & 30 & 43 & 45 & - \\
IV & $16-30$ & 30 & 43 & 45 & 10 \\
V & $31-41$ & 30 & 43 & 45 & 60 \\
VI & $42-49$ & 30 & 43 & 45 & 110 \\
VII & $50-56$ & 30 & 43 & 15 & 110 \\
VIII & $57-64$ & 30 & 43 & 0 & 110 \\
IX & $65-94$ & Adjust COD/ $/ \mathrm{NO}_{3}{ }^{-}-\mathrm{N}$ ratio to explore the best conditions for coupling &
\end{tabular}

ratio was about $1: 1.25: 0.25$. The parameters used in eqn (2) are the actual operating parameters.

$$
\begin{gathered}
\mathrm{NH}_{4}{ }^{+}+1.32 \mathrm{NO}_{2}{ }^{-}+0.066 \mathrm{HCO}_{3}{ }^{-}+0.13 \mathrm{H}^{+} \rightarrow 1.02 \mathrm{~N}_{2} \\
+0.26 \mathrm{NO}_{3}{ }^{-}+0.066 \mathrm{CH}_{2} \mathrm{O}_{0.5} \mathrm{~N}_{0.15}+2.03 \mathrm{H}_{2} \mathrm{O} \\
\mathrm{NTR}=\frac{1.25\left(\mathrm{NH}_{4 \mathrm{eff}}{ }^{+}-\mathrm{NH}_{4 \text { inf }}{ }^{+}\right)}{\mathrm{NO}_{3 \text { inf }}{ }^{-}-\mathrm{NO}_{3 \mathrm{eff}}{ }^{-}-0.25\left(\mathrm{NH}_{4 \mathrm{eff}^{+}}-\mathrm{NH}_{4 \text { inf }}{ }^{+}\right)} \times 100 \%
\end{gathered}
$$

\subsection{Analytical methods}

The influent and effluent samples were collected on a daily basis and were analyzed immediately. All samples were analyzed after filtration through $0.45 \mu \mathrm{m}$ pore size Millipore filter units. $\mathrm{NH}_{4}{ }^{+}-\mathrm{N}, \mathrm{NO}_{2}{ }^{-}-\mathrm{N}$, and $\mathrm{NO}_{3}{ }^{-}-\mathrm{N}$ were measured with a Lachat Quik Chem8500 Flow Injection Analyzer (Lachat Instruments, Milwaukee, USA). The $\mathrm{pH}$ and temperature were measured with the WTW 340i pH probe (WTW company, Germany). The total nitrogen (TN) concentration was calculated via the sum of ammonium nitrogen, nitrite nitrogen, and nitrate nitrogen concentration.

\section{Results and discussion}

\subsection{Start-up of the DEAMOX process in the continuous reactor}

The immobilizing method was used in the anammox reactor to evenly distribute the anaerobic ammonium oxidation bacteria in the reactor. Due to the long growth cycle of anaerobic ammonium oxidation bacteria, ${ }^{\mathbf{1 3}}$ the immobilizing method could either decrease or completely avoid the loss of anammox sludge during operation.

Phase I was the stable operation period of the immobilized anaerobic ammonium oxidation. The hydraulic retention time (HRT) was $4 \mathrm{~h}$, the operating temperature was maintained at about $30{ }^{\circ} \mathrm{C}$, and the $\mathrm{pH}$ of the influent was controlled at $7.5 \pm$ 0.1 . These operating conditions remained unchanged during the start-up process. As shown in Fig. 2, the removal rates of
$\mathrm{NH}_{4}{ }^{+}-\mathrm{N}$ and $\mathrm{NO}_{2}{ }^{-}-\mathrm{N}$ were $100 \%$ and $82.6 \%$, respectively. The TN removal rate was $76.5 \%$.

During phase II, $10 \mathrm{mg} \mathrm{L}^{-1}$ and $40 \mathrm{mg} \mathrm{L}^{-1} \mathrm{NO}_{3}{ }^{-}-\mathrm{N}$ were added to the influent, respectively. The addition of $\mathrm{NO}_{3}{ }^{-}-\mathrm{N}$ had no impact on the nitrogen removal rate of anaerobic ammonium oxidation bacteria or the reaction ratio of $1: 1.25: 0.25$. After 16 days, to cultivate heterotrophic denitrifying bacteria, a small amount of COD (about $10 \mathrm{mg} \mathrm{L}^{-1}$ ) was added to the reactor and the $\mathrm{COD} / \mathrm{NO}_{3}{ }^{-}-\mathrm{N}$ ratio was about 0.23 . Under these conditions, denitrifying bacteria could freely distribute according to their growth needs. Due to the low biomass of the denitrifying bacteria in the reactor, the COD could not be effectively removed at the very beginning. Therefore, to reduce or completely avoid the influence of COD on anammox, the COD in the influent was controlled at a lower concentration. Previous studies showed that the addition of a small amount of COD did not impact the anaerobic ammonium oxidation. ${ }^{14-17}$ As shown in Fig. 2, the addition of COD did not impact anammox bacteria and the effluent nitrate concentration decreased slightly, indicating that the denitrifying bacteria gradually grew in the reactor. After 30 days of operation, the effluent nitrate concentration remained

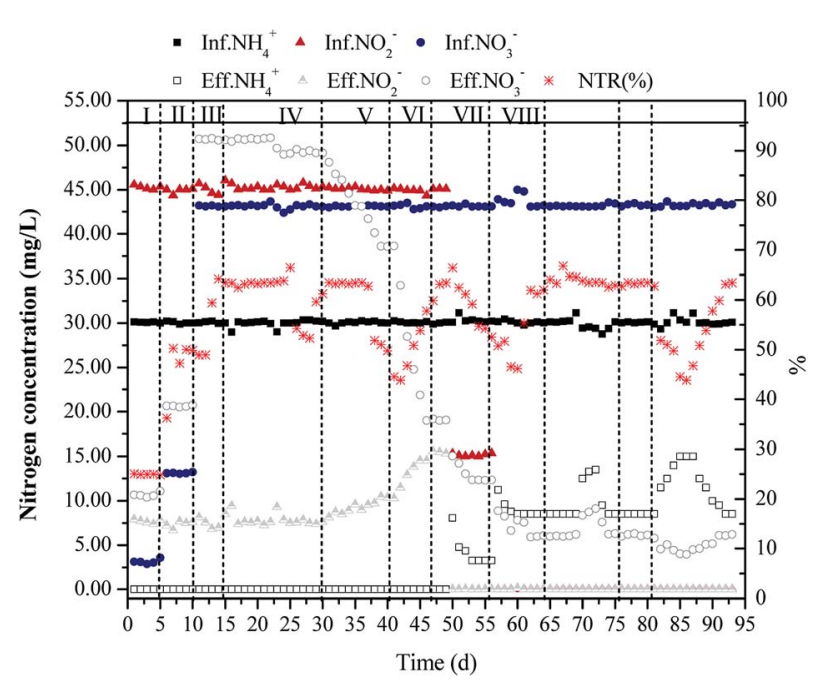

Fig. 2 Start-up of partial denitrification coupled with immobilization of anammox in continuous upflow reactor. 
stable at about $49.12 \mathrm{mg} \mathrm{\textrm {L } ^ { - 1 }}$ and decreased by $1.71 \mathrm{mg} \mathrm{L}^{-1}$ compared to before addition of COD. Due to the lower amount of added COD, most COD was used to meet the growing needs of the microorganism. Therefore, the denitrification effect was not prominent and the NTR value was approximately 0 .

During phase $\mathrm{V}$, the dosage of COD increased to 60 and $110 \mathrm{mg} \mathrm{L}{ }^{-1}$, with $\mathrm{COD} / \mathrm{NO}_{3}{ }^{-}-\mathrm{N}$ ratios of approximately 1.39 and 2.56, respectively. During the phase, the denitrification efficiency continued to increase. During phase VI, the removal rate of $\mathrm{NO}_{3}{ }^{-}-\mathrm{N}$ reached $27.4 \%$ and $72.8 \%$. On the $41^{\text {st }}$ day, the NTR value slowly increased to $24.4 \%$, indicating that a gradual increase of the partial denitrification efficiency. When the dosage of COD increased to $120 \mathrm{mg} \mathrm{L}^{-1}$, the removal rate of $\mathrm{NO}_{3}{ }^{-}-\mathrm{N}$ continued to improve; however, the NTR value did not increase significantly, indicating that the increase of COD did not enhance the partial denitrification efficiency and the increased COD caused the $\mathrm{NO}_{3}{ }^{-}-\mathrm{N}$ directly converting to $\mathrm{N}_{2}$. However, when the concentration of $\mathrm{NO}_{2}{ }^{-}-\mathrm{N}$ in the influent gradually decreased to 0 , the NTR value increased significantly even if the dosage of COD remained unchanged. As shown in Fig. 2, on the $49^{\text {th }}$ day, when the influent concentration of $\mathrm{NO}_{2}{ }^{-}-\mathrm{N}$ decreased to $15 \mathrm{mg} \mathrm{L}^{-1}$, the NTR value rapidly increased and stabilized at $48.9 \%$. When the concentration of the influent $\mathrm{NO}_{2}{ }^{-}-\mathrm{N}$ decreased, part of electron acceptor required for anammox were provided via partial denitrification; therefore, the ability of anaerobic ammonium oxidation bacteria to compete with denitrifying bacteria for intermediate product of denitrification $\left(\mathrm{NO}_{2}{ }^{-}-\mathrm{N}\right)$ was enhanced. Moreover, an increasing amount of $\mathrm{NO}_{3}{ }^{-}-\mathrm{N}$ was reduced to $\mathrm{NO}_{2}{ }^{-}-\mathrm{N}$ rather than $\mathrm{N}_{2}$. However, the NTR value increased with the decreasing concentration of $\mathrm{NO}_{2}{ }^{-}-\mathrm{N}$ in the influent and partial denitrification was enhanced without changing other conditions. At this time, the removal rate of $\mathrm{NO}_{3}{ }^{-}-\mathrm{N}$ increased correspondingly, which stabilized at $87.0 \%$ on the $56^{\text {th }}$ day. In theory, if $1 \mathrm{~g} \mathrm{NO}_{3}{ }^{-}-$ $\mathrm{N}$ was completely reduced to $\mathrm{N}_{2}$, about $2.86 \mathrm{~g}$ of $\mathrm{BOD}_{5}$ was required. In fact, the proportion was higher than this ratio because of various reasons. However, $1 \mathrm{~g} \mathrm{NO}_{3}{ }^{-}-\mathrm{N}$ only required about $1.14 \mathrm{~g} \mathrm{BOD}_{5}$ when it was reduced to $\mathrm{NO}_{2}{ }^{-}-\mathrm{N}$ instead of $\mathrm{N}_{2}$. Under the condition that the amount of the carbon source was identical and relatively insufficient, the higher the NTR value, the more $\mathrm{NO}_{3}{ }^{-}-\mathrm{N}$ could be reduced.

After 56 days, no nitrite was present in the influent and only $\mathrm{NH}_{4}{ }^{+}-\mathrm{N}, \mathrm{NO}_{3}{ }^{-}-\mathrm{N}$, and carbon sources were added to achieve partial denitrification coupling anammox without adding any nitrite. When the nitrite concentration was 0 in the influent, the NTR value and the removal rate of $\mathrm{NO}_{3}{ }^{-}-\mathrm{N}$ increased immediately, which kept at $63.5 \%$ and $98.4 \%$ on the $64^{\text {th }}$ day, respectively.

After stable operation for a period of time, to determine the optimum range of $\mathrm{COD} / \mathrm{NO}_{3}{ }^{-}-\mathrm{N}$ ratio, the influent concentration of COD was changed to adjust the $\mathrm{COD} / \mathrm{NO}_{3}{ }^{-}-\mathrm{N}$ ratio of the influent, with the concentration of $\mathrm{NH}_{4}{ }^{+}-\mathrm{N}$ and $\mathrm{NO}_{3}{ }^{-}-\mathrm{N}$ in the influent remaining unchanged. On the $65^{\text {th }}$ day, the influent $\mathrm{COD} / \mathrm{NO}_{3}{ }^{-}-\mathrm{N}$ ratio decreased to around 2.3. The NTR value and the removal rate of $\mathrm{NO}_{3}{ }^{-}-\mathrm{N}$ remained unchanged. On the $70^{\text {th }}$ day, both the NTR value and the removal rate of $\mathrm{NO}_{3}{ }^{-}-\mathrm{N}$ rapidly decreased to $52.2 \%$ and $88.1 \%$ when the $\mathrm{COD} / \mathrm{NO}_{3}{ }^{-}-\mathrm{N}$ ratio decreased to 2.1 , respectively. To prevent the deterioration of the operation state, the ratio was restored to 2.5 on the $73^{\text {rd }}$ day. The nitrogen removal efficiency of the coupling reactor rapidly recovered to the original stable state after only 4 days. On the $76^{\text {th }}$ day, the ratio increased to 2.7; however, the coupling efficiency was not decreased, indicating that the increase in COD concentration did not impact the effect of partial denitrification and that COD was in excess under this condition. On the $82^{\text {nd }}$ day, the ratio continued to increase to 2.9. As shown in Fig. 2, the removal rate of $\mathrm{NO}_{3}{ }^{-}-\mathrm{N}$ still remained at a high level, while the NTR value rapidly decreased to about $45.0 \%$. The nitrogen removal efficiency of the coupling reactor has been gradually recovered with a recovery time of seven days, since the COD/ $\mathrm{NO}_{3}{ }^{-}-\mathrm{N}$ changed to 2.5 on the $88^{\text {th }}$ day. Although the efficiencies of the reactor had all recovered rapidly, the recovery needed longer with higher $\mathrm{COD} / \mathrm{NO}_{3}{ }^{-}-\mathrm{N}$ ratio than with lower $\mathrm{COD} /$ $\mathrm{NO}_{3}{ }^{-}-\mathrm{N}$ ratio.

\subsection{Impact of increasing $\mathrm{pH}$ on the coupling system}

According to the studies of Glass et al. ${ }^{18}$ and Li et al., ${ }^{19}$ the increase of $\mathrm{pH}$ promotes the accumulation of nitrite nitrogen during the denitrification process. Glass et al. studied the accumulation of nitrite in denitrification process in sequencing batch reactors at $\mathrm{pH}$ values of $6.5,7,7.5,8.5$, and 9. When the $\mathrm{pH}$ was 6.5 and 7 , the denitrification efficiency of nitrate was inhibited. However, the denitrification efficiency was significant when for $\mathrm{pH}$ values of 7.5, 8.5, and 9. With increasing influent $\mathrm{pH}$, the NTR value continued to increase and the peaks of

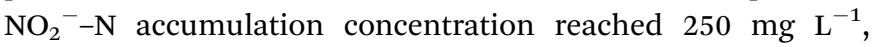
$500 \mathrm{mg} \mathrm{L}^{-1}$, and $900 \mathrm{mg} \mathrm{L}^{-1}$, respectively. Li et al. increased the $\mathrm{pH}$ value to about 9.2 via utilizing denitrification alkalization in the denitrification process with high nitrate nitrogen concentration (nitrogen load was about $55 \mathrm{~kg} \mathrm{~N} \mathrm{~m}^{-3} \mathrm{~d}^{-1}$ ) in the influent. The accumulation concentration of $\mathrm{NO}_{2}{ }^{-}-\mathrm{N}$ reached as high as $451.1 \pm 49.0 \mathrm{mg} \mathrm{L}^{-1}$. Therefore, in this study, the $\mathrm{pH}$ of the influent increased from about 7.5 to 8.0 and 8.5 , which was within the optimum range of the anaerobic ammonium oxidation reaction. The impact of $\mathrm{pH}$ on the coupling reactor was investigated. As shown in Fig. 3, from the $94^{\text {th }}$ to the $109^{\text {th }}$ day and from the $110^{\text {th }}$ to the $119^{\text {th }}$ day, the $\mathrm{pH}$ of the influent maintained at 8.0 and 8.5. The results indicate that the ammonia nitrogen removal rate and the NTR value of the coupling reactor decreased continuously in response to increasing the influent $\mathrm{pH}$ to 8.0 ; however, they tended to stabilize at the $102^{\text {nd }}$ day, decreasing from $75.1 \%$ and $63.4 \%$ to $58.1 \%$ and $54.6 \%$, respectively. After the $109^{\text {th }}$ day, the further increase of $\mathrm{pH}$ in influent to 8.5 noticeably weakened the nitrogen removal efficiency of the coupling reactor. The NTR value and ammonia nitrogen removal rate decreased to $49.4 \%$ and $36.1 \%$, respectively. The increased range of $\mathrm{pH}$ matched the optimum reaction conditions for anaerobic ammonium oxidation. Thus, the increase of $\mathrm{pH}$ observed in this study had little impact when anaerobic ammonium oxidation bacteria contended for electron acceptor, $\mathrm{NO}_{2}{ }^{-}-\mathrm{N}$, it mainly affected the accumulation of $\mathrm{NO}_{2}{ }^{-}-\mathrm{N}$ in the denitrification process. The accumulation of $\mathrm{NO}_{2}{ }^{-}-\mathrm{N}$ decreased with increasing $\mathrm{pH}$, which was not consisted with the study results of Glass and Li. The 


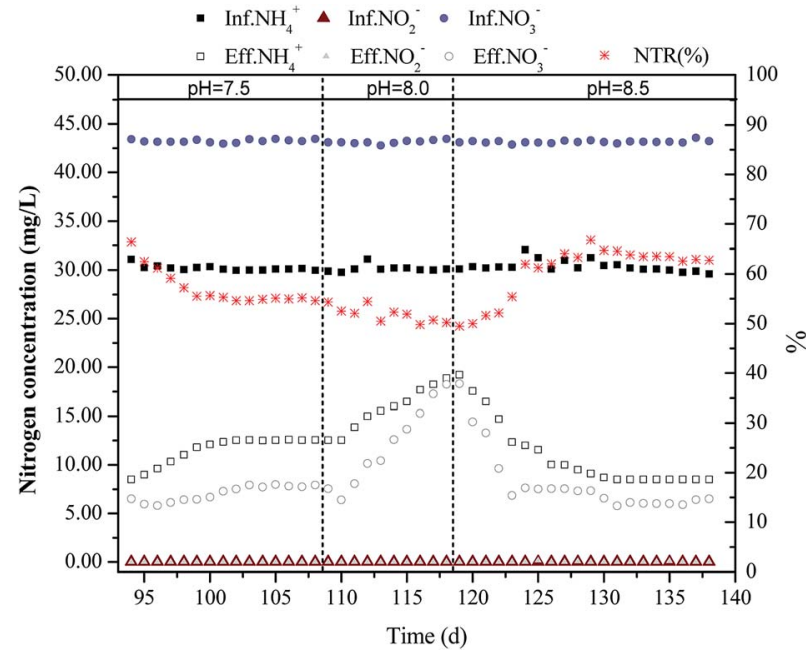

Fig. 3 Effect of $\mathrm{pH}$ on partial denitrification coupled with immobilization of anammox.

reason for this inconsistency was likely the different types of heterotrophic denitrifying bacteria cultivated. On the $120^{\text {th }}$ day, the $\mathrm{pH}$ of the influent recovered to the initial state and the efficiency of coupling reactor also slowly recovered. After 11 days, the coupling reactor recovered to the optimal state and operated stably. Compared to changing the addition volume of the carbon source, the change of $\mathrm{pH}$ had a greater impact on the recovery of coupling efficiency and the recovery time was longer. However, due to the small increase of $\mathrm{pH}$, the range of which was within the optimum range of the anaerobic ammonium oxidation reaction, the recovery time was relatively short.

\subsection{Adding a solid carbon source (PCL) to increase the total nitrogen removal rate}

PCL is a type of biodegradable polymer (BDPs) synthesized from petroleum as raw material and belongs to the aliphatic polyesters, which could be used as carbon source to effectively degrade nitrate nitrogen in wastewater. Furthermore, many studies have reported that PCL had good biodegradability and biocompatibility, and thus it is widely used in biological denitrification..$^{20}$ PCL is characterized as a slow-release carbon source, which follows an easily controlled process, This characteristic was the premise of the practical application of PCL. ${ }^{21}$ In this study, PCL was used as a solid carbon source and about $100 \mathrm{~g}$ PCL particles were fixed on the upper part of the reactor by means of fine meshes, which were added on flow-separated balls to remove the nitrate nitrogen produced by anaerobic ammonia oxidation, thus increasing the total nitrogen removal rate of the reactor. Chu et al. ${ }^{22}$ used PCL as a biological denitrification fixed-bed carrier to remove the $\mathrm{NO}_{3}{ }^{-}-\mathrm{N}$ in the wastewater via denitrification. It was predicted that $1.6-3.7 \mathrm{~g}$ PCL should be consumed if $1 \mathrm{~g} \mathrm{NO}_{3}{ }^{-}-\mathrm{N}$ was removed. Therefore, the $\mathrm{NO}_{3}{ }^{-}-\mathrm{N}$ in the effluent of coupling reactor was about $6.5 \mathrm{mg} \mathrm{L}^{-1}$ and the hydraulic retention time of the reactor (HRT) was about $4 \mathrm{~h}$. Consequently, $100 \mathrm{~g}$ PCL particles can be used at least $100 /(6.5 \times 3.7 \times 6 \times 24 / 4 / 1000)=116$ days to $100 /(6.5 \times$ $1.6 \times 6 \times 24 / 4 / 1000)=267$ days until they were consumed

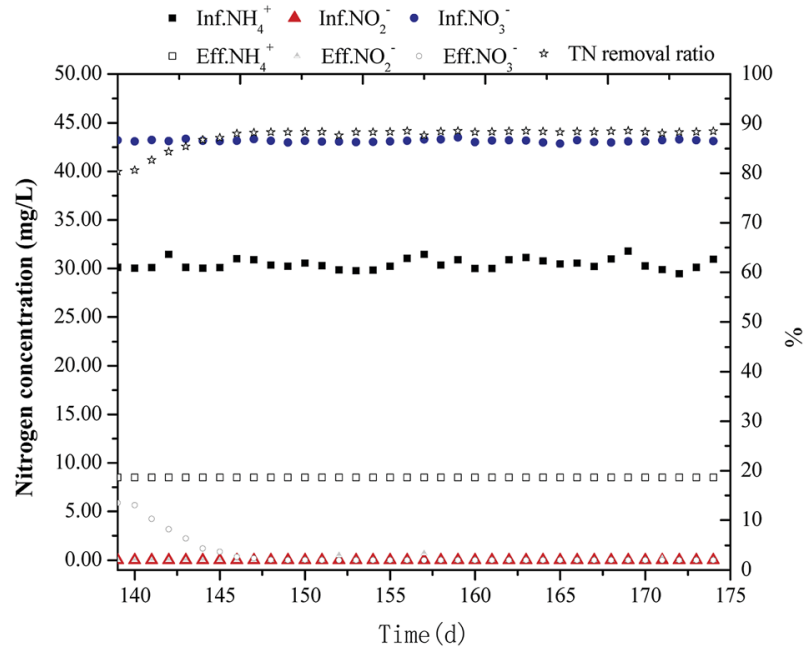

Fig. 4 Changes of nitrogen concentration and TN removal rate in effluent with addition of solid carbon source.

completely. PCL was added after the reactor ran for 139 days. Fig. 4 shows the influent and effluent of the reactor after PCL addition. It could be seen that since the heterotrophic denitrifying bacteria in the reactor were mainly distributed in the lower part of the reactor, the capacity of bacteria to decompose PCL was poor. Therefore, a small amount of PCL could be transferred to the liquid phase at the very beginning. As a result of this poor denitrification efficiency, the concentration of $\mathrm{NO}_{3}{ }^{-}-\mathrm{N}$ in the effluent did not decrease significantly. After a period of operation, the denitrification efficiency increased rapidly. Since the denitrifying bacteria grew fast, the concentration of $\mathrm{NO}_{3}{ }^{-}-\mathrm{N}$ in the effluent was closed to 0 after 12 days. Since then, the reactor continued to operate stably. The addition of PCL contributed to the removal rate of the TN, which increased from $80.3 \%$ to $88.5 \%$. Based on the DEAMOX process, the complete denitrification with PCL as solid carbon source could be successfully realized and stably operated. This also provided an effective method for the treatment of nitrogen wastewater. When the reactor operated for 156 days, a large number of denitrifying organisms adhered to the PCL particles. This result was consistent with most previous study results. ${ }^{23}$

\section{Conclusion}

The novel DEAMOX process for low $\mathrm{C} / \mathrm{N}$ wastewater was successfully established based on a continuous flow reactor of immobilized anammox. The electron acceptor required for anammox was completely derived from the $\mathrm{NO}_{2}{ }^{-}-\mathrm{N}$ produced via partial denitrification. Appropriately increasing the $\mathrm{pH}$ of the influent to 8.0 and 8.5 decreased the coupling efficiency and the NTR value decreased to $49.4 \%$. When the $\mathrm{pH}$ recovered to the initial state, the coupling efficiency recovered rapidly after 11 days. After only 12 days, the complete denitrification of the solid carbon source was successfully started up on the basis of the DEMOX process. The nitrate produced by the anaerobic ammonium oxidation reaction was completely removed, and the removal rate of $\mathrm{TN}$ increased from $80.3 \%$ to $88.5 \%$. 


\section{Conflicts of interest}

There are no conflicts to declare.

\section{Acknowledgements}

This research was supported by the National Major Project [2017ZX07103] and Natural Science Foundation of Beijing Municipality [8172012].

\section{References}

$1 \mathrm{~W}$. Zhu, J. Li, H. Dong, D. Wang and P. Zhang, Biodegradation, 2017, 28, 437-452.

2 L. Zhang, Y. Narita, L. Gao, M. Ali, M. Oshiki, S. Ishii and S. Okabe, Water Res., 2017, 125, 249-258.

3 X. Tang, Y. Guo, B. Jiang and S. Liu, Water Res., 2018, 136, 95103.

4 A. Pedrouso, I. Aiartza, N. Morales, J. R. Vázquez-Padín, F. Rogalla, J. L. Campos, A. Mosquera-Corral and A. V. del Rio, Sep. Purif. Technol., 2018, 200, 94-101.

5 J. Wu, Environ. Sci. Pollut. Res., 2017, 24, 25839-25848.

6 S. Kalyuzhnyi, M. Gladchenko, A. Mulder and B. Versprille, Water Res., 2006, 40, 3637-3645.

7 S. Cao, S. Wang, Y. Peng, C. Wu, R. Du, L. Gong and B. Ma, Bioresour. Technol., 2013, 149, 570-574.

8 R. Du, S. Cao, B. Li, M. Niu, S. Wang and Y. Peng, Water Res., 2017, 108, 46-56.
9 W. Li, Z. Y. Cai, Z. J. Duo, Y. F. Lu, K. X. Gao, G. Abbas, M. Zhang and P. Zheng, Chemosphere, 2017, 182, 532-538.

10 S. Ge, Y. Peng, S. Wang, C. Lu, X. Cao and Y. Zhu, Bioresour. Technol., 2012, 114, 137-143.

11 K. Isaka, Y. Date, T. Sumino and S. Tsuneda, Appl. Microbiol. Biotechnol., 2007, 76, 1457-1465.

12 J. Li, W. Zhu, H. Dong and D. Wang, Biodegradation, 2017, 28, 245-259.

13 M. Strous, J. J. Heijnen, J. G. Kuenen and M. S. M. Jetten, Appl. Microbiol. Biotechnol., 1998, 50, 589-596.

14 S. Jenni, S. E. Vlaeminck, E. Morgenroth and K. M. Udert, Water Res., 2014, 49, 316-326.

15 J. S. Guillén, Y. Yimman, C. L. Vazquez, D. Brdjanovic and J. B. Van Lier, Water Sci. Technol., 2014, 69, 2079-2084.

16 C. Chen, X. Huang, C. Lei, T. C. Zhang and W. Wu, Bioresour. Technol., 2013, 148, 172-179.

17 S. Q. Ni, J. Y. Ni, D. L. Hu and S. Sung, Bioresour. Technol., 2012, 110, 701-705.

18 C. Glass and J. Silverstein, Water Res., 1998, 32, 831-839.

19 W. Li, X. Y. Shan, Z. Y. Wang, X. Y. Lin, C. X. Li, C. Y. Cai, G. Abbas, M. Zhang, L. D. Shen, Z. Q. Hu and H. P. Zhao, Water Res., 2016, 88, 758-765.

20 L. Chu and J. Wang, Chem. Eng. J., 2011, 170, 220-225.

21 Y. Xu, T. L. Qiu, M. L. Han, J. Li and X. M. Wang, Procedia Environ. Sci., 2011, 10, 72-77.

22 L. Chu and J. Wang, Chemosphere, 2013, 91, 1310-1316.

23 W. Wu, L. Yang and J. Wang, Environ. Sci. Technol., 2013, 97, 2725-2733. 